\title{
Composite ammonium glycyrrhizin has hepatoprotective effects in chicken hepatocytes with lipopolysaccharide/enrofloxacin-induced injury
}

\author{
XUEWEN GUO, WENYANG LI, RAN AN, MEI HUANG and ZUGONG YU \\ Department of Veterinary Preventive Medicine, Laboratory of Veterinary Pharmacology and Toxicology, \\ College of Veterinary Medicine, Nanjing Agricultural University, Nanjing, Jiangsu 210095, P.R. China
}

Received October 9, 2017; Accepted May 17, 2018

DOI: $10.3892 /$ etm.2020.9180

\begin{abstract}
Composite ammonium glycyrrhizin (CAG) has anti-inflammatory activity. Lipopolysaccharide (LPS) and enrofloxacin (ENR) induce liver damage; however, the mechanism underlying LPS/ENR-induced hepatic injury remains to be elucidated. In the present study, the mechanism of LPS/ENR-induced liver injury was investigated in vitro and the protective effects of CAG were also evaluated. Primary chicken hepatocytes were isolated and a model of LPS/ENR-induced hepatocyte injury was established. mRNA and protein expression levels were evaluated by reverse transcription-quantitative polymerase chain reaction and western blot, respectively. LPS/ENR exposure significantly increased supernatant aspartate aminotransferase (AST) and alanine aminotransferase (ALT). In the LPS/ENR-treated group, glutathione (GSH) and the antioxidant enzymes, superoxide dismutase (SOD), catalase (CAT) and glutathione peroxidase (GPx) activities were significantly increased. Flow cytometry results revealed that the apoptotic rate significantly increased in the LPS/ENR-treated group compared with the control, while treatment with CAG given $24 \mathrm{~h}$ prior to LPS/ENR caused a significant decrease in the apoptotic rate compared with the model group. Furthermore, CAG treatment reversed LPS/ENR-associated alterations in the mRNA and protein expression of Caspase-3, apoptosis regulator Bcl-2 (Bcl-2) and Bcl-2 associated X-protein. The mitochondrial membrane potential significantly decreased and the mitochondrial microstructure was notably altered following exposure to LPS/ENR compared with the control. In conclusion, these results suggested that LPS/ENR-treated hepatocytes were
\end{abstract}

Correspondence to: Dr Zugong Yu, Department of Veterinary Preventive Medicine, Laboratory of Veterinary Pharmacology and Toxicology, College of Veterinary Medicine, Nanjing Agricultural University, 6 Tongwei Road, Nanjing, Jiangsu 210095, P.R. China

E-mail: yuzugong@njau.edu.cn

Key words: liver injury, drug protection, lipopolysaccharide/ enrofloxacin, composite ammonium glycyrrhizim damaged via apoptotic signaling pathways and CAG prevented LPS/ENR-induced hepatocyte injury.

\section{Introduction}

Lipopolysaccharide (LPS) is a component of Gram-negative bacterial cell walls, which releases a variety of inflammatory factors that lead to hepatic necrosis (1). Antioxidant enzyme levels and free radical scavenging have been reported to decrease following LPS exposure $(2,3)$. Drug-induced liver injury (DILI) is a leading limitation of therapeutic drug use and often leads to post-marketing drug withdrawal and attrition due to toxicity during drug development $(4,5)$. Between 2004 and 2007 antibacterial agents accounted for $45.5 \%$ of DILI in the USA, including amoxicillin/clavulanate multiples, third generation cephalosporins, fluoroquinolones and amidealcohols (6-8). Enrofloxacin (ENR) is a fluoroquinolone, which is widely used for the prevention and treatment of poultry-associated bacterial infections, however the long-term use of ENR may induce liver injury (9). Previous reports $(10,11)$ have confirmed that ENR induces endotoxin release by disrupting the outer membrane of organisms (12).

Composite ammonium glycyrrhizin (CAG) is composed of ammonium glycyrrhizin, glycine and methionine (13). The primary bioactive components of licorice root are glycyrrhizin and glycyrrhizic acid (GA), which are commonly used in Asia to treat patients with chronic hepatitis $(14,15)$. As an ammonium salt of glycyrrhizic acid, ammonium glycyrrhizin also has protective functions. GA may promote liver cell proliferation, thereby promoting liver regeneration (16). GA also exhibits antiviral, anti-tumor and immunomodulatory activity (17-19). In previous studies, it has been demonstrated that GA may prevent liver injury by suppressing lipid peroxidation reactions, which enhances the ability of the liver to scavenge free radicals and resist free radical damage in the liver (20). CAG has been reported to be effective as an anti-inflammatory, anticancer, antihepatotoxic and antioxidant agent $(13,16)$. In addition, its antiradical activity has been reported to be responsible for its anti-inflammatory actions $(13,21,22)$.

Although the beneficial effects of CAG have been extensively studied, it remains unknown as to whether it protects the liver from a combination of LPS- and ENR-induced injuries. 
Therefore, the aim of the present study was to establish an in vitro LPS/ENR-induced liver model and utilize this model to evaluate the protective effects of CAG, whilst also examining the molecular mechanisms underlying the protective effects.

\section{Materials and methods}

Reagents and materials. CAG $(2 \mathrm{mg} / \mathrm{ml})$ was produced by the authors in our laboratory [ammonium glycyrrhizin (2.8 g; Shaanxi FUJIE Pharmaceutical Co., Ltd., Xianyang, China), glycine $(2 \mathrm{~g})$ and methionine (2 $\mathrm{g}$, Tianjin Tianyao Pharmaceuticals Co., Ltd., Tianjin, China) filled with water to $1,000 \mathrm{~g})]$. ENR was purchased from the National Institute for the Control of Pharmaceutical and Biological Products (Beijing, China). LPS (E. coli L-2880; Sigma-Aldrich; Merck KGaA, Darmstadt, Germany). Dulbecco's modified Eagle's medium (DMEM) was purchased from Hyclone; GE Healthcare Life Sciences (Logan, UT, USA). Primary antibodies against apoptosis regulator Bcl-2 (Bcl-2; cat. no. 610538; 1:1,000; BD Biosciences, Franklin Lakes, NJ, USA), Bcl-2 associated X-protein (Bax; cat. no. orb334986; 1:1,000; Biorbyt Ltd., Cambridge, UK), caspase-3 (cat. no. ab115183; 1:1,000, Abcam, Cambridge, USA), $\beta$-actin (1:5,000; Sigma-Aldrich; Merck $\mathrm{KGaA}, \mathrm{A} 5441)$ and secondary horseradish peroxidase-labeled goat anti-rabbit IgG (cat. no. 4201-100; 1:1,000; Shanghai Pufei Biotechnology Co., Ltd., Shanghai, China) were obtained.

Cell isolation and culture. A total of 1230 day old male Hailan chickens (mean weight, $1.5 \pm 0.2 \mathrm{~kg}$ ) were purchased from Qinglong Mountain (Nanjing, China) and housed at $22^{\circ} \mathrm{C}$ with ventilation using 12-h light/dark cycles. Animals had free access to food and water and were fasting $12 \mathrm{~h}$ prior to experiments. Hepatocytes $(23,24)$ were isolated from the chickens (using the two-stage, collagenase type IV perfusion method via the portal vein. Briefly, the livers were perfused with solution A [33 mM 4-hydroxyethylpiperazine ethanesulfonic acid (HEPES), $127.8 \mathrm{mM} \mathrm{NaCl}, 3.15 \mathrm{mM} \mathrm{KCl}, 0.7 \mathrm{mM} \mathrm{Na}_{2} \mathrm{HPO}_{4}$ $\mathrm{x} 12 \mathrm{H}_{2} \mathrm{O}$ and $0.6 \mathrm{mM}$ EGTA; $\left.\mathrm{pH} 7.6\right]$ and solution $\mathrm{B}(33 \mathrm{mM}$ HEPES, $127.8 \mathrm{mM} \mathrm{NaCl}, 3.15 \mathrm{mM} \mathrm{KCl}, 0.7 \mathrm{mM} \mathrm{Na}_{2} \mathrm{HPO}_{4}$ $\mathrm{x} 12 \mathrm{H}_{2} \mathrm{O}$ and $3 \mathrm{mM} \mathrm{CaCl}_{2} ; \mathrm{pH}$ 7.6) at room temperature at a flow rate of $10-20 \mathrm{ml} / \mathrm{min}$ for $15 \mathrm{~min}$. A total of $100 \mathrm{ml}$ 0.5\% collagenase type IV buffer (C0016; NanJing HoldBio E-Commerce Co., Ltd., Nanjing, China) was perfused for $20-25 \mathrm{~min}$ at $37^{\circ} \mathrm{C}$ at a flow rate of $20 \mathrm{ml} / \mathrm{min}$. The hepatocytes were separated from the other cellular components by centrifugation at $167.7 \mathrm{x} \mathrm{g}$ for $3 \mathrm{~min}$ at $37^{\circ} \mathrm{C}$. Isolated cells were washed twice in solution B supplemented with $0.2 \%$ bovine serum albumin (BSA; Sigma Aldrich; Merck KGaA). MTT stock solution ( $5 \mu \mathrm{l} ; 5 \mathrm{mg} / \mathrm{ml})$ was added in each well and cells were incubated in a humidified incubator with an atmosphere of $5 \% \mathrm{CO}_{2}$ for $4 \mathrm{~h}$ at $37^{\circ} \mathrm{C}$. Absorbance at $570 \mathrm{~nm}$ was measured using a microplate reader. Cell yield varied between 4 and $5 \times 10^{8}$ cells/liver and the cell viability varied between 90 and $95 \%$ as determined by trypan blue exclusion (0.04\%; Beijing Solarbio Science \& Technology Co., Ltd., Beijing, China). Adherent cells were digested using trypsin to prepare single cell suspension. Cell suspension was mixed with $0.4 \%$ trypan blue solution $(9: 1)$. Following $3 \mathrm{~min}$ at room temperature, living and dead cells were counted. Dead cells appeared blue and living cells were colorless/transparent. The viable cell rate was defined as: Viable cell rate $(\%)=$ total viable cells/total cells.

The present study was approved by the Animal Ethics Committee of Nanjing Agricultural University (Nanjing, China).

In-vitro LPS/ENR-induced hepatocyte injury model. Chicken hepatocytes were plated at a density of $5 \times 10^{5}$ cells in 96-well cell plates and cultured for $48 \mathrm{~h}$ at $37^{\circ} \mathrm{C}$ in DMEM. LPS $(30 \mu \mathrm{g} / \mathrm{ml})$ and different concentrations of ENR $(40-120 \mu \mathrm{g} / \mathrm{ml})$ were added to determine the optimal concentration. Cytotoxicity was measured using an MTT assay. MTT $(0.1 \%)$ was added to the cell plates and incubated at $37^{\circ} \mathrm{C}$ for $4 \mathrm{~h}$. The medium was added to $150 \mu \mathrm{l}$ dimethyl sulfoxide to dissolve the purple formazan and the absorbance was measured at a wavelength of $570 \mathrm{~nm}$ using a microplate reader.

Treatment groups. The cells were divided into four groups: i) Control group, not administered with CAG or exposed to LPS/ENR; ii) model group, administered LPS/ENR (30/80 $\mu \mathrm{g} / \mathrm{ml})$ for $24 \mathrm{~h}$; iii) CAG group, administered CAG $400 \mu \mathrm{g} / \mathrm{ml}$; and iv) combined group, pretreated with CAG $(25,50,100,200$ and $400 \mu \mathrm{g} / \mathrm{ml})$ for $24 \mathrm{~h}$ prior to LPS/ENR $(30 / 80 \mu \mathrm{g} / \mathrm{ml})$.

Analysis of alanine aminotransferase (ALT) and aspartate aminotransferase (AST) enzyme levels in the cell culture supernatant. ALT and AST are liver enzyme markers (1). These two enzymes were measured by spectrophotometric analysis. Cell supernatants of the different groups were obtained by centrifugation $\left(1,006 \mathrm{x} \mathrm{g} ; 10 \mathrm{~min} ; 4^{\circ} \mathrm{C}\right)$ and the activity of ALT (C009-1; Jiancheng Bioengineering Institute Co., Ltd., Nanjing, China) and AST (C010-1; Jiancheng Bioengineering Institute Co., Ltd.) were determined according to the manufacturer's protocol.

Enzyme activity in hepatocytes. The hepatocytes were lysed in a radioimmunoprecipitation assay buffer (RIPA; Jiancheng Bioengineering Institute Co., Ltd.) on ice and centrifuged at $7,280 \mathrm{x}$ g for $15 \mathrm{~min}$ at $4^{\circ} \mathrm{C}$. The cell lysate supernatant was aspirated and stored at $-20^{\circ} \mathrm{C}$ prior to glutathione (GSH) assays (reduced glutathione assay kit; A006-1; Jiancheng Bioengineering Institute Co., Ltd.), superoxide dismutatse (SOD) assays (SOD assay kit; A001-3; Jiancheng Bioengineering Institute Co., Ltd.), catalase (CAT) assays (CAT assay kit; A007-1-1; Jiancheng Bioengineering Institute Co., Ltd.), glutathione peroxidase (GPx) assays (GPx assay kit; A005; Jiancheng Bioengineering Institute Co., Ltd.) and malondialdehyde (MDA) assays (MDA assay kit; A003-1; Jiancheng Bioengineering Institute Co., Ltd.) according to the manufacturer's protocols. The protein concentration of each sample was determined using the bicinchoninic acid protein quantitation cassette.

Flow cytometry analysis. In normal viable cells propidium iodide (PI) and Annexin V are negative, while in early apoptotic cells Annexin V is positive and PI is negative. In late apoptotic cells Annexin V and PI are positive, while in dead cells Annexin V is negative and PI is positive. Cells following $24 \mathrm{~h}$ LPS/ENR treatment were collected $(560 \mathrm{x} \mathrm{g}$; $5 \mathrm{~min}$; $4^{\circ} \mathrm{C}$ ) and stained using an Annexin V-fluorescein (FITC)/PI 
Table I. Primer sequences of the target genes used for polymerase chain reaction.

Primer sequence $\left(5^{\prime} \rightarrow 3^{\prime}\right)$

\begin{tabular}{lll}
\cline { 2 - 3 } Gene & \multicolumn{1}{c}{ Forward } & \multicolumn{1}{c}{ Reverse } \\
\hline$\beta$-actin & ATGTGGATCAGCAAGCAGGAGTA & TTTATGCGCATTTATGGGTTTTGT \\
Bax & GTGATGGCATGGGACATAGCTC & TGGCGTAGACCTTGCGGATAA \\
Bcl-2 & ATCGTCGCCTTCTTCGAGTT & ATCCCATCCTCCGTTGTCCT \\
Caspase-3 & AAGGCTCCTGGTTTATTC & CTGCCACTCTGCGATTTA
\end{tabular}

Bcl-2, apoptosis regulator Bcl-2; Bax, Bcl-2 associated X-protein.

Apoptosis Detection kit (BD Biosciences) according to manufacturer's protocol. The cells collected were then analyzed by flow cytometry using a BD FACS Calibur Cell Sorting system (BD Biosciences, Franklin Lakes, NJ, USA) and FlowJo v10 (FlowJo LLC, Ashland, OR, USA).

Extraction of total RNA and reverse transcription-quantitative polymerase chain reaction ( $R T-q P C R)$. Chicken hepatocytes following $24 \mathrm{~h}$ treatment with LPS/ENR were collected (7,280 x g; $15 \mathrm{~min}, 4^{\circ} \mathrm{C}$ ) and total RNA was extracted using an RNAiso Plus kit (Takara Biotechnology Co., Ltd., Dalian, China). RT was performed using the PrimeScript ${ }^{\mathrm{TM}}$ RT reagent Kit with gDNA Eraser (RR037A; Takara Biotechnology Co., Ltd.) at $37^{\circ} \mathrm{C}$ for $15 \mathrm{~min}$, followed by $85^{\circ} \mathrm{C}$ for $5 \mathrm{sec}$. RNA concentrations were detected using a Qubit RNA Assay kit and a Qubit 2.0 fluorometer (Invitrogen; Thermo Fisher Scientific, Inc., Waltham, MA, USA). The primer sequences of the genes used for PCR are listed in Table I. SYBR green premix (RR820A; Takara Biotechnology Co., Ltd.) was used for qPCR analysis. The PCR thermocycling conditions were as follows: $95^{\circ} \mathrm{C}$ for $30 \mathrm{sec}$, followed by 40 cycles of $95^{\circ} \mathrm{C}$ for $5 \mathrm{sec}$ and $60^{\circ} \mathrm{C}$ for $30 \mathrm{sec}$. Quantification was based on the $2^{-\Delta \Delta \mathrm{Cq}}$ method (25) and $\beta$-actin was used as the housekeeping gene.

Western blotting analysis. Total protein was extracted from chicken hepatocytes using a RIPA buffer. Protein concentrations were determined using bicinchoninic acid assays. Equal amounts of protein $(100 \mu \mathrm{g})$ were separated on $10 \%$ SDS-PAGE and then transferred to polyvinylidene difluoride membranes. Membranes were blocked with 5\% BSA at room temperature for $2 \mathrm{~h}$ followed by incubation with primary antibodies overnight at $4^{\circ} \mathrm{C}$. Membranes were incubated with secondary antibodies for $1 \mathrm{~h}$ at room temperature. Following, membranes were washed with TBST and immunoreactive bands were detected by using enhanced chemiluminescence (Vazyme, Piscataway, NJ, USA). The western blot bands were analyzed using ImageJ software (1.46r; National Institutes of Health, Bethesda, MD, USA).

Measurement of Caspase-3 activity. Caspase-3 activity was measured in all groups following $24 \mathrm{~h}$ of LPS/ENR treatment using a commercial Caspase-3 Colorimetric Assay kit (C1115; Beyotime Institute of Biotechnology, Shanghai, China) according to the manufacturer's protocol.
Transmission electron microscopy (TEM). Cells were fixed with $2.5 \%$ glutaraldehyde in $0.1 \mathrm{M}$ sodium phosphate buffer (pH 7.2) for $3 \mathrm{~h}$ at $4^{\circ} \mathrm{C}$. Fixed cells were subsequently cut into sections for TEM $(10-100 \mathrm{~nm})$. The sections were stained with $2 \%$ uranyl acetate at $37^{\circ} \mathrm{C}$ for $30 \mathrm{~min}$ and embedded in osmium tetroxide at $37^{\circ} \mathrm{C}$ for $30 \mathrm{~min}$ and observed under a Hitachi TEM (Hitachi, Ltd., Tokyo, Japan).

Mitochondrial membrane potential (MMP) assay. Hepatocyte MMP was measured using the membrane-sensitive JC-1 dye and analyzed with a fluorescence microscope. JC-1 staining solution (1 ml; Mitochondrial Membrane Potential kit; Beyotime Institute of Biotechnology) was added to each well and mixed. Cells were incubated for $20 \mathrm{~min}$ at $37^{\circ} \mathrm{C}$ in an incubator with the JC-1 stain. Following incubation the supernatant was aspirated, cells were washed twice with JC-1 buffer solution at room temperature for $20 \mathrm{sec}, 2 \mathrm{ml}$ DMEM were added and samples were observed under a fluorescence microscope (magnification, x100).

Statistical analysis. All data are expressed as the mean \pm standard deviation, from $\geq 3$ repeats. Data were analyzed using SPSS software version 19.0 (IBM Corp., Armonk, NY, USA). One-way analysis of variance with Dunnett's post hoc test was used for the comparison of multiple groups. $\mathrm{P}<0.05$ was considered to indicate a statistically significant difference.

\section{Results}

Establishing of an LPS/ENR-induced model of liver injury. Assessment of the variations in hepatocyte cell viability and morphological evaluation following LPS/ENR treatment were performed. The results demonstrated that LPS/ENR treatment decreased the viability of cells in a dose-dependent manner (Fig. 1A). When cells were treated with LPS/ENR 30/80-30/120 $\mu \mathrm{g} / \mathrm{ml}$ they demonstrated evident reduced cell viability. When the concentration of LPS/ENR was $30 / 100 \mu \mathrm{g} / \mathrm{ml}$, the cell viability was $22.57 \pm 0.43 \%$. Exposure of cells to $30 / 120 \mu \mathrm{g} / \mathrm{ml}$ LPS/ENR injury led to a notable reduction in cell number and these cells exhibited morphological alterations, including the disruption of cell membranes and nuclear fragmentation compared with the control cells. At LPS/ENR 30/80 $\mu \mathrm{g} / \mathrm{ml}$ the cell viability was $48.27 \pm 2.50 \%$ and the cell shape was irregular with clear disruption of the cell membrane. Therefore, LPS/ENR 30/80 $\mu \mathrm{g} / \mathrm{ml}$ was determined 

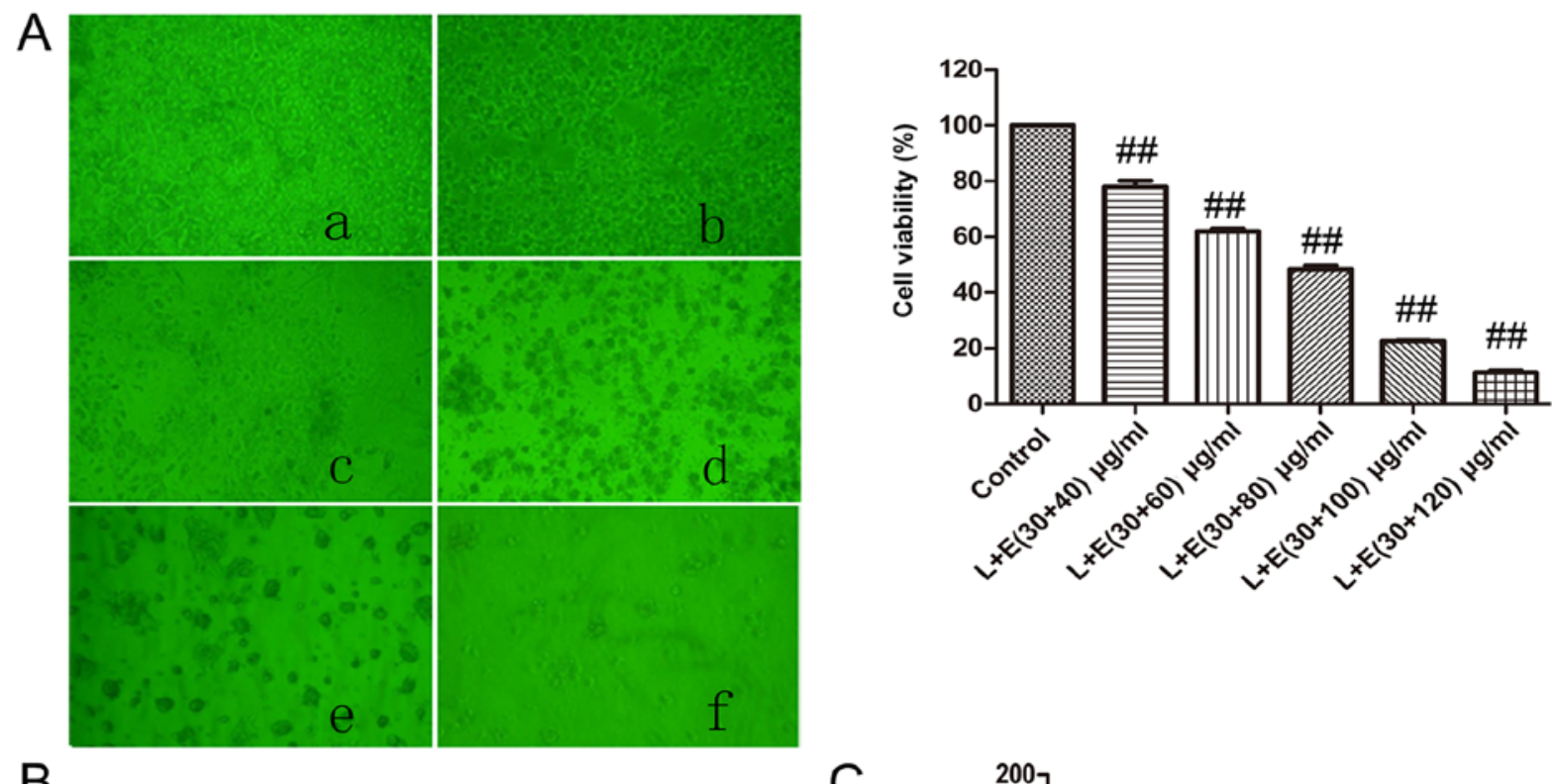

$\mathrm{B}$

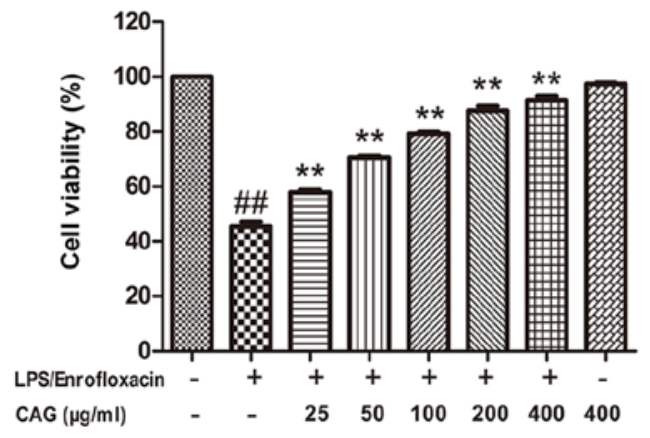

D

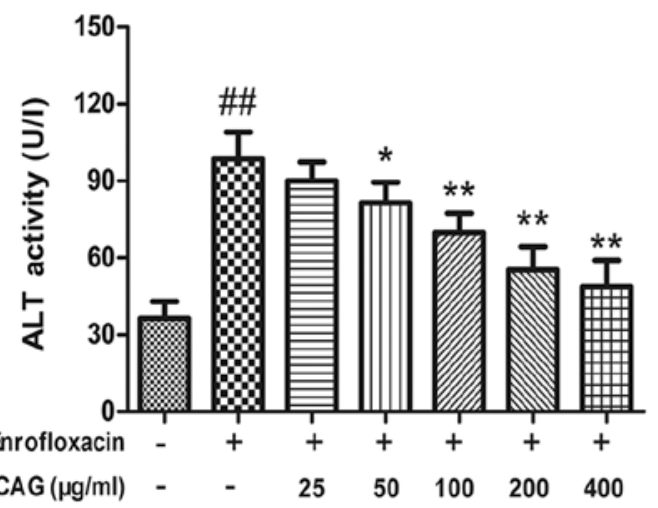

$\mathrm{F}$

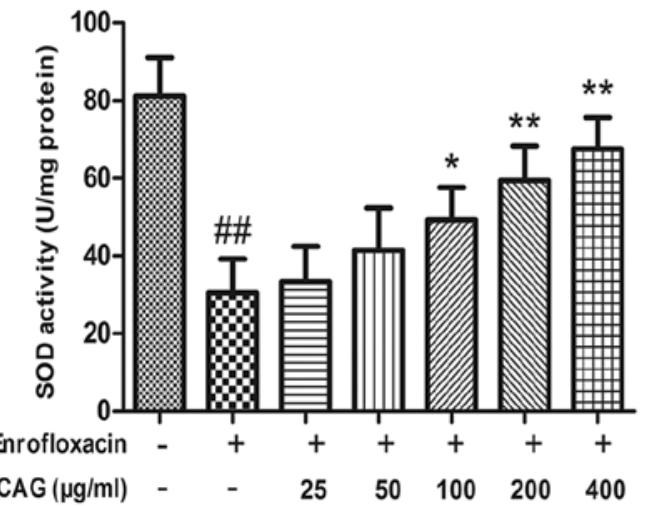

C
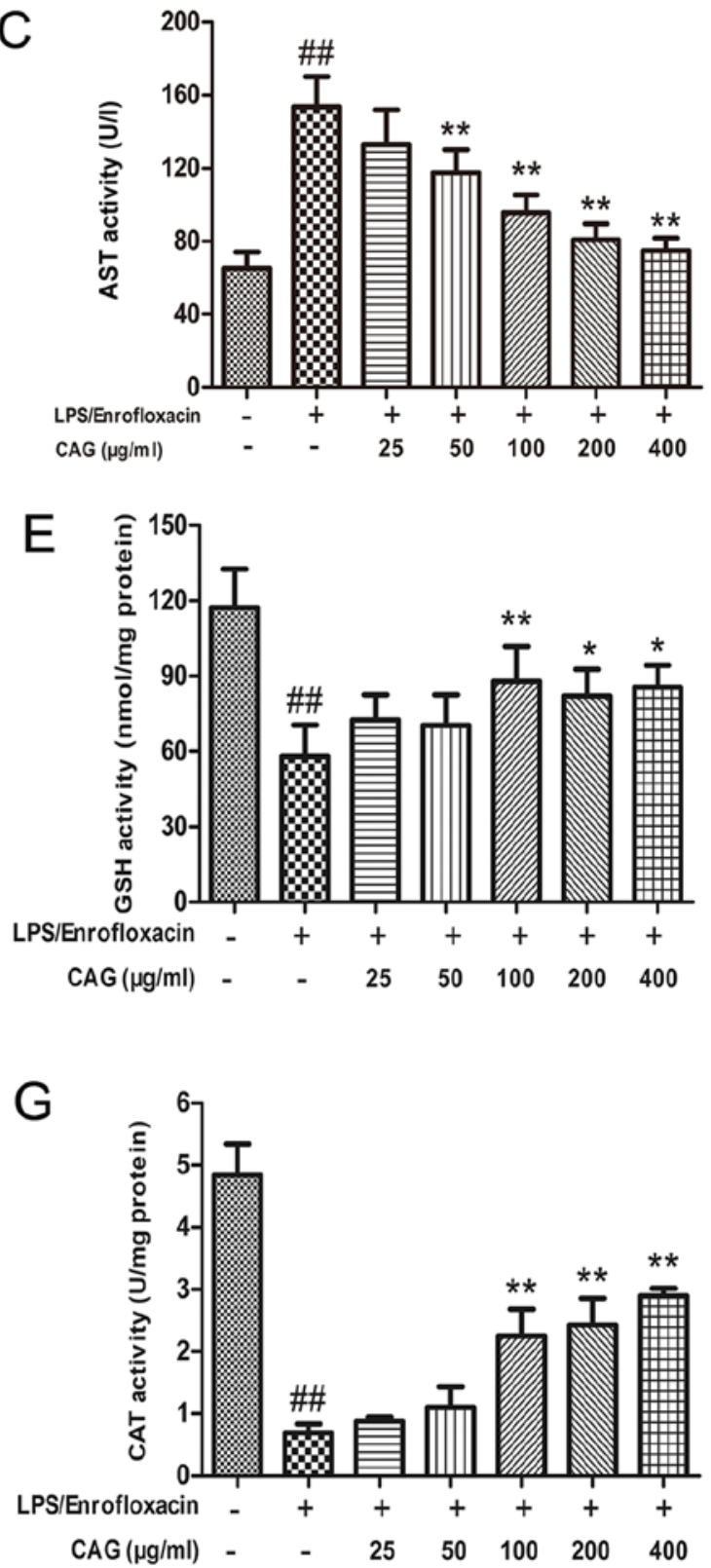

Figure 1. (A) Effect of different concentrations of LPS/ENR on cytomorphology (magnification, x20) and hepatocyte viability. Images of (a) normal cells; and cells treated with (b) $30 / 40 \mu \mathrm{g} / \mathrm{ml}$; (c) $30 / 60 \mu \mathrm{g} / \mathrm{ml}$; (d) $30 / 80 \mu \mathrm{g} / \mathrm{ml}$; (e) $30 / 100 \mu \mathrm{g} / \mathrm{ml}$; and (f) $30 / 120 \mu \mathrm{g} / \mathrm{ml} \mathrm{LPS} / \mathrm{ENR}$. The effect of CAG on (B) cell viability, (C) AST, (D) ALT, (E) GSH, (F) SOD and (G) CAT activity was determined. 

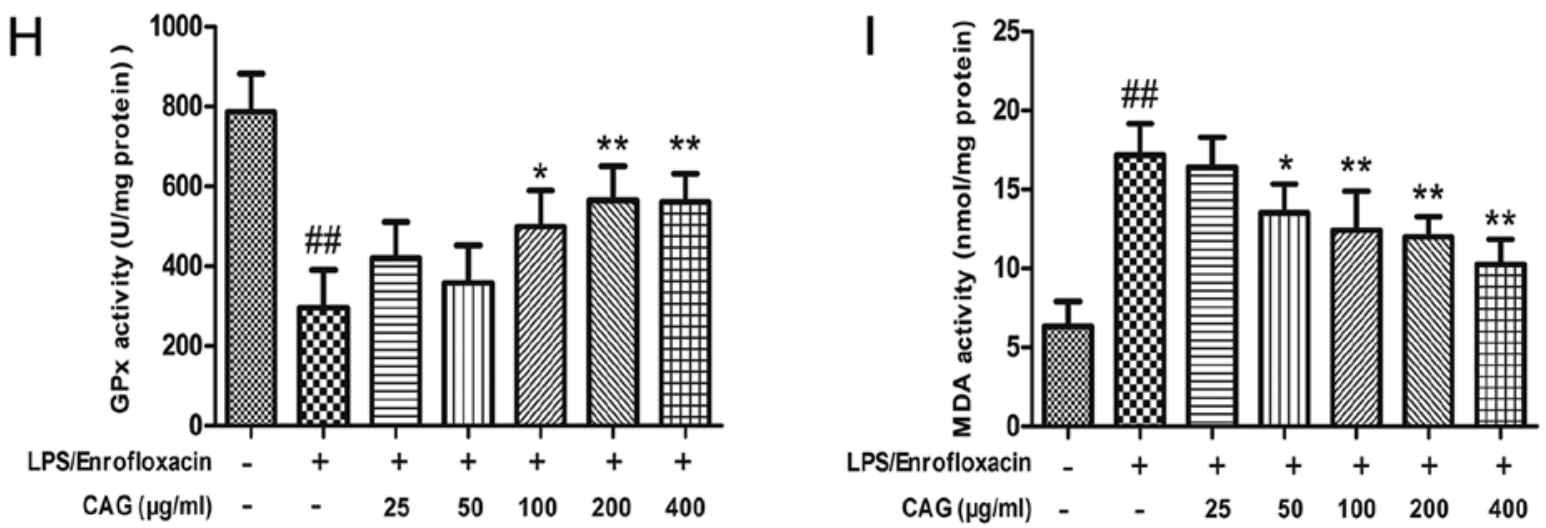

Figure 1. Continued. The effect of CAG on (H) GPx and (I) MDA activity was determined. LPS/enrofloxacin was given at a dose of 30/80 $\mu$ g/ml. Hepatocytes were collected following CAG treatment for $24 \mathrm{~h}$. Data are expressed as the mean \pm standard deviation $(\mathrm{n}=3)$. ${ }^{\# \#} \mathrm{P}<0.01 \mathrm{vs}$. the control group; ${ }^{*} \mathrm{P}<0.05,{ }^{* *} \mathrm{P}<0.01$ vs. the model group treated with 30/80 $\mu \mathrm{g} / \mathrm{ml}$ LPS/ENR. LPS or L, lipopolysaccharide; CAG, composite ammonium glycyrrhizin; AST, aspartate aminotransferase; ALT, alanine aminotransferase; GSH, glutathione; SOD, superoxide dismutase; CAT, catalase; GPx, glutathione peroxidase; MDA, malondialdehyde; ENR or E, enrofloxacin.

to be the most appropriate concentration and was used in the model groups for all further experimentation.

CAG attenuates LPS/ENR-induced hepatocyte injury. ALT and AST activities were measured in the supernatant and the cell viability was evaluated using an MTT assay. Following treatment with CAG $(400 \mu \mathrm{g} / \mathrm{ml})$ the cell viability was $97.39 \pm 0.75 \%$, which was similar to the negative control group and indicated the non-toxic nature of CAG (Fig. 1B). Treatment with LPS/ENR $(30 / 80 \mu \mathrm{g} / \mathrm{ml})$ induced a significant elevation in ALT (Fig. 1C) and AST (Fig. 1D) concentrations $(\mathrm{P}<0.01)$ compared with the control, while treatment with $\mathrm{CAG}$ $(50-400 \mu \mathrm{g} / \mathrm{ml})$ caused a dose-dependent decrease compared with the model group $(\mathrm{P}<0.05$ and $\mathrm{P}<0.01)$.

LPS/ENR $(30 / 80 \mu \mathrm{g} / \mathrm{ml})$ treatment of hepatocytes significantly reduced the cell viability of the hepatocytes compared with the control group $(\mathrm{P}<0.01$; Fig. 1B). Hepatocytes treated with CAG demonstrated a dose dependent improvement in cell growth and all groups treated with CAG had significantly improved cell viability compared with the model group (all $\mathrm{P}<0.01)$.

MDA and assays of the antioxidant enzymes GSH, SOD, CAT and GPx. Treating hepatocytes with LPS/ENR $(30 / 80 \mu \mathrm{g} / \mathrm{ml})$ for $24 \mathrm{~h}$ caused a significant reduction in activity of $\mathrm{GSH}$ ( $\mathrm{P}<0.01$; Fig. 1E), SOD ( $\mathrm{P}<0.01$; Fig. 1F), CAT $(\mathrm{P}<0.01$; Fig. 1G) and GPx $(\mathrm{P}<0.01$; Fig. $1 \mathrm{H})$ compared with the control group. Treatment with LPS/ENR caused a significant elevation in MDA levels ( $\mathrm{P}<0.01$; Fig. 1I) compared with the control group. CAG treatment provided a protective effect as evidenced by the restoration of these biomarkers. The highest dose of CAG $(400 \mu \mathrm{g} / \mathrm{ml})$ attenuated protein MDA levels and caused an increase in GSH protein levels and the activities of the SOD, CAT and GPx antioxidant enzymes $(\mathrm{P}<0.01$; Fig. 1E-I).

Apoptosis assay using Annexin V-FITC/PI staining and flow cytometry. To confirm apoptotic activity, flow cytometry analysis of hepatocytes was performed using dual stain Annexin V-FITC/PI (Fig. 2). In the control group there was a high percentage of surviving cells $(91.40 \pm 3.74 \%)$ and a low percentage of early apoptotic $(2.69 \pm 0.79 \%)$ and late apoptotic $(3.05 \pm 1.81 \%)$ cells. In the LPS/ENR group the percentage of surviving cells $(17.26 \pm 3.98 \%)$ was significantly decreased compared with the control group. The number of early apoptotic $(73.03 \pm 3.36 \%)$ and late apoptotic $(10.42 \pm 2.15 \%)$ cells were significantly increased following LPS/ENR $(30 / 80 \mu \mathrm{g} / \mathrm{ml})$ treatment in comparison with the control group. The number of early apoptotic cells $(66.92 \pm 2.73,41.73 \pm 4.07,31.32 \pm 2.74 \%$, $13.82 \pm 2.07$ and $11.53 \pm 1.17 \%$ ) notably reduced in a dose-dependent manner with increasing concentrations of CAG $(25,50$, 100,200 and $400 \mu \mathrm{g} / \mathrm{ml}$, respectively). All groups treated with CAG had a significantly reduced number of apoptotic cells compared with the model group $(73.03 \pm 3.36 \%$; $\mathrm{P}<0.05)$.

CAG modifies caspase-3, Bax and Bcl-2 mRNA expression. Treatment with LPS/ENR $(30 / 80 \mu \mathrm{g} / \mathrm{ml})$ significantly increased hepatocyte caspase-3 (Fig. 3A) and Bax (Fig. 3B) mRNA expression 19.45 \pm 1.87 - and 11.43 \pm 2.35 -fold, respectively compared with the control group $(\mathrm{P}<0.01)$. Treatment with 25-400 $\mu \mathrm{g} / \mathrm{ml}$ CAG significantly inhibited Caspase-3 expression $(\mathrm{P}<0.01$; Fig. 3A). Treatment with $\geq 50 \mu \mathrm{g} / \mathrm{ml}$ CAG significantly inhibited Bax mRNA expression $(\mathrm{P}<0.05$; Fig. 3B). LPS/ENR $(30 / 80 \mu \mathrm{g} / \mathrm{ml})$ treatment markedly suppressed Bcl-2 expression, while CAG treatment at doses of 100 and $200 \mu \mathrm{g} / \mathrm{ml}$ significantly increased Bcl-2 mRNA expression compared with the control $(\mathrm{P}<0.01$; Fig. $3 \mathrm{C})$. Interestingly, at $400 \mu \mathrm{g} / \mathrm{ml} \mathrm{Bcl-2} \mathrm{mRNA}$ was not significantly decreased $(\mathrm{P}>0.05)$.

CAG treatment affects the protein expression of caspase-3, Bax and $B c l-2$. Western blot analysis was performed to confirm the apoptotic data (Fig. 3D). Bcl-2 and caspase-3 protein expression levels were significantly upregulated in the LPS/ENR group compared with the control group $(\mathrm{P}<0.01$; Fig. $3 \mathrm{E}$ and $\mathrm{F})$. The results also revealed that Bax protein expression was notably increased in the LPS/ENR group, while this was significantly reversed by CAG treatment $(25,200$ and $400 \mu \mathrm{g} / \mathrm{ml})$ for $24 \mathrm{~h}$ prior to LPS/ENR treatment $(\mathrm{P}<0.01$; Fig. 3G). Caspase-3 activity was further examined using a colorimetric assay; the results demonstrated that $24 \mathrm{~h}$ exposure to LPS/ENR 

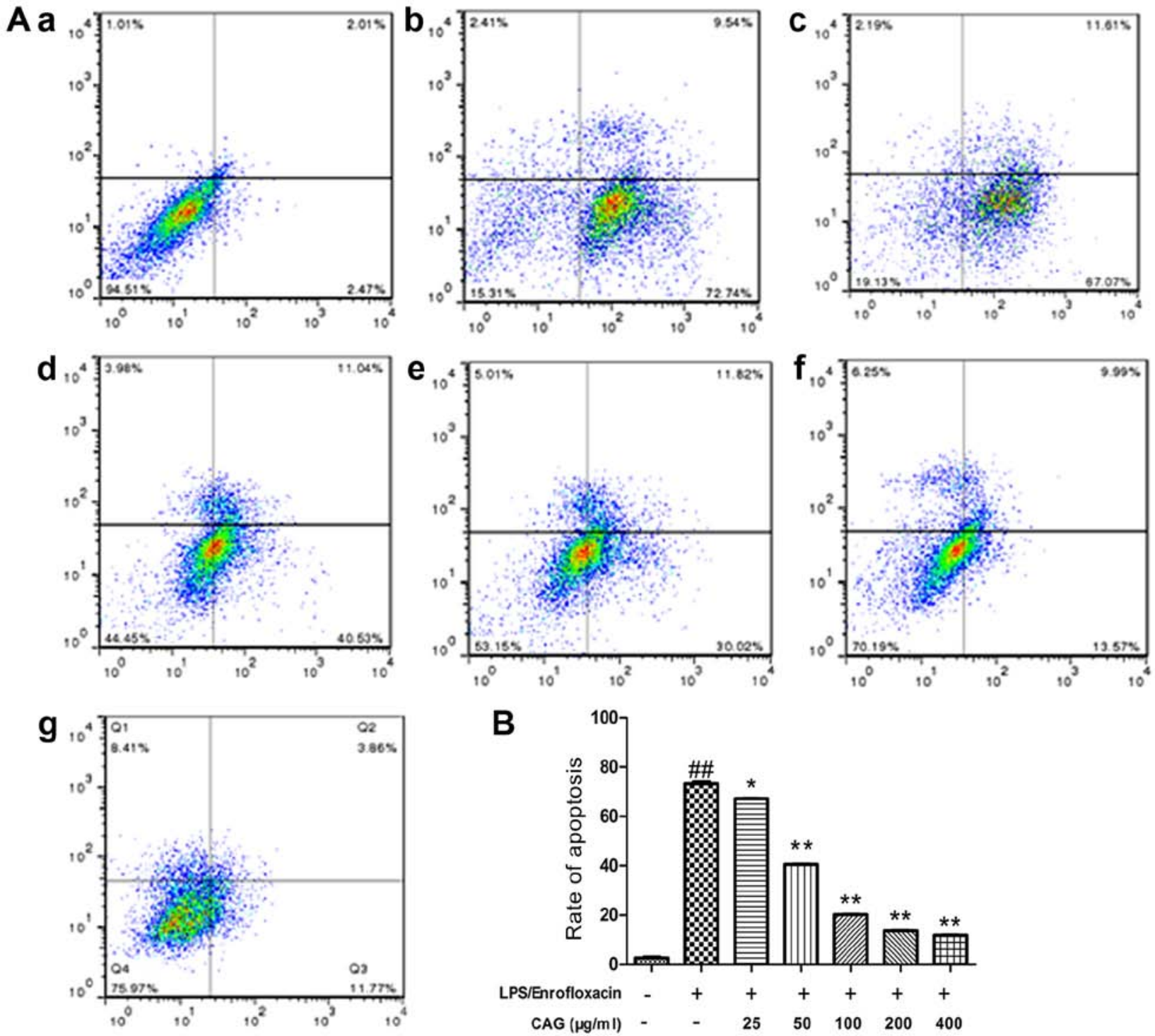

Figure 2. (A) Apoptosis was assessed by Annexin V-fluorescein isothiocyanate/propidium iodide staining via flow cytometry assay in hepatocytes. Apoptosis was measure in (a) control group, (b) model group, (c) CAG group ( $25 \mu \mathrm{g} / \mathrm{ml})$, (d) CAG group (50 $\mu \mathrm{g} / \mathrm{ml}$ ), (e) CAG group (100 $\mu \mathrm{g} / \mathrm{ml})$, (f) CAG group (200 $\mu \mathrm{g} / \mathrm{ml})$ and (g) CAG group $(400 \mu \mathrm{g} / \mathrm{ml})$. (B) Analysis of the total percentage of early apoptotic cells in different groups. Data are expressed as the mean \pm standard deviation $(\mathrm{n}=3) .{ }^{\# \#} \mathrm{P}<0.01$ vs. the control group; ${ }^{*} \mathrm{P}<0.05,{ }^{* *} \mathrm{P}<0.01$ vs. the model group. LPS, lipopolysaccharide; CAG, composite ammonium glycyrrhizin; model group, cells treated with $30 / 80 \mu \mathrm{g} / \mathrm{ml}$ LPS/enrofloxacin.

caused a significant increase in caspase-3 activity compared with the control $(\mathrm{P}<0.01)$. In addition, when the hepatocytes were exposed to CAG $(50-400 \mu \mathrm{g} / \mathrm{ml})$ the caspase-3 activity significantly decreased compared with the LPS/ENR group (all $\mathrm{P}<0.01$; Fig. $3 \mathrm{H}$ ).

Alterations in mitochondrial ultrastructure and MMP. Mitochondria serve an important role in the apoptotic-signaling pathway (26). In the present study, normal ultrastructure features were observed in the control group, including a round nucleus, nuclear membrane integrity and normal mitochondrial cristae (Fig. 4A). In the LPS/ENR treatment group, the mitochondria were swollen with clear vacuolization and loss of the crest (Fig. 4B). Following treatment with CAG $(25-400 \mu \mathrm{m} / \mathrm{ml})$ for $24 \mathrm{~h}$ these modifications were alleviated (Fig. 4C-G). The MMP was also investigated using JC-1 dye. In normal mitochondria, JC-1 accumulates in the mitochondrial matrix to form polymers and the polymer emits intense red fluorescence. Unhealthy mitochondria may be present in the cytoplasm in monomeric form due to a decrease or loss of membrane potential and produces green fluorescence (10). In the model group green fluorescence was increased compared with red fluorescence. However, in the CAG group, red fluorescence was increased compared with green fluorescence (Fig. 4H).

\section{Discussion}

LPS- and drug-induced liver toxicity are common causes of liver injury (1). Common compound liver injury models use Bacille Calmette Guerin and LPS or D-galactosamine and LPS (1) and to the best of the authors' knowledge, there are no previous reports investigating antimicrobial drugs in combination with LPS-induced liver injury. In the present study, primary cells were separated using a modified two-step colla- 
A
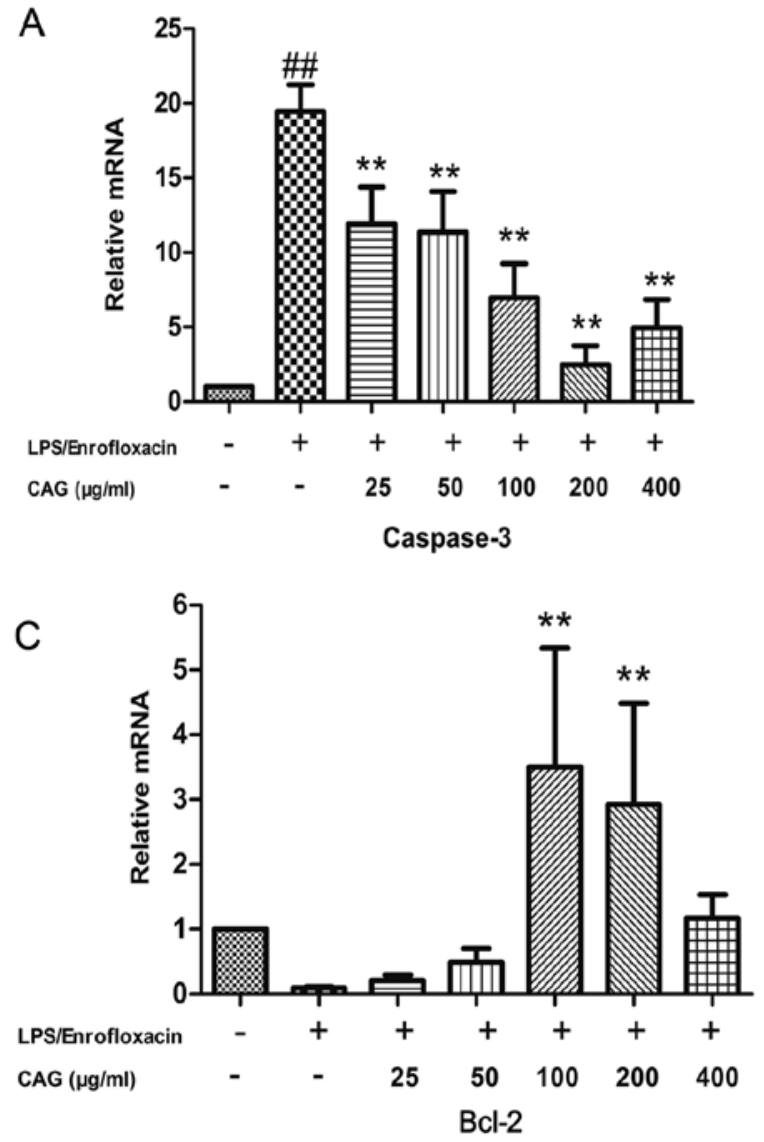

E
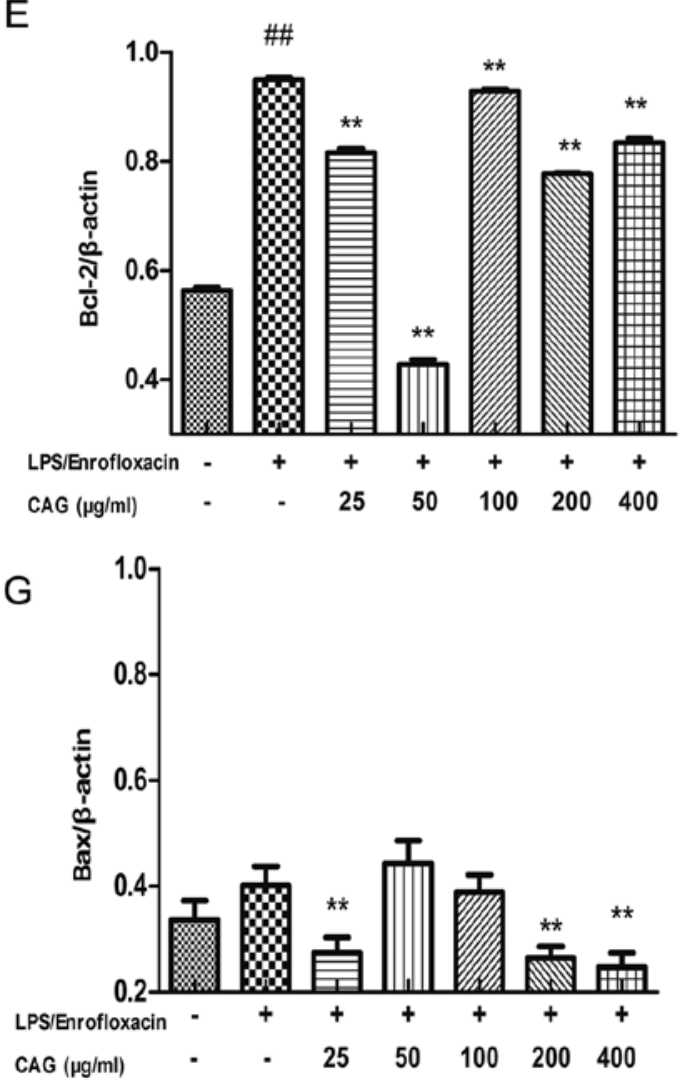

B

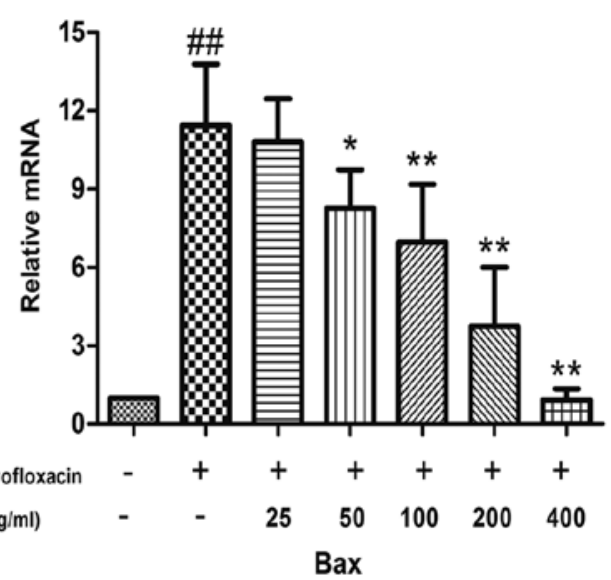

D

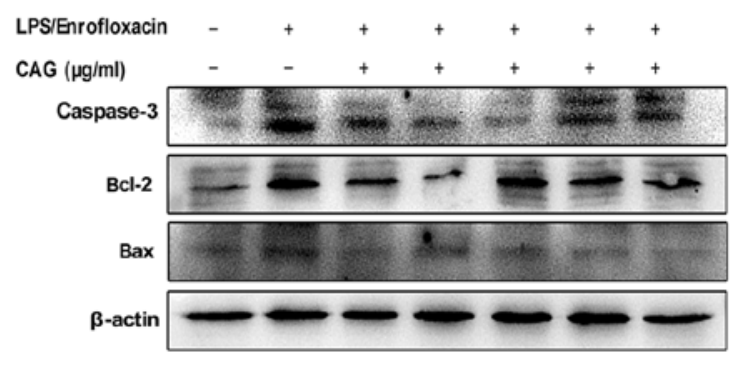

$\mathrm{F}$
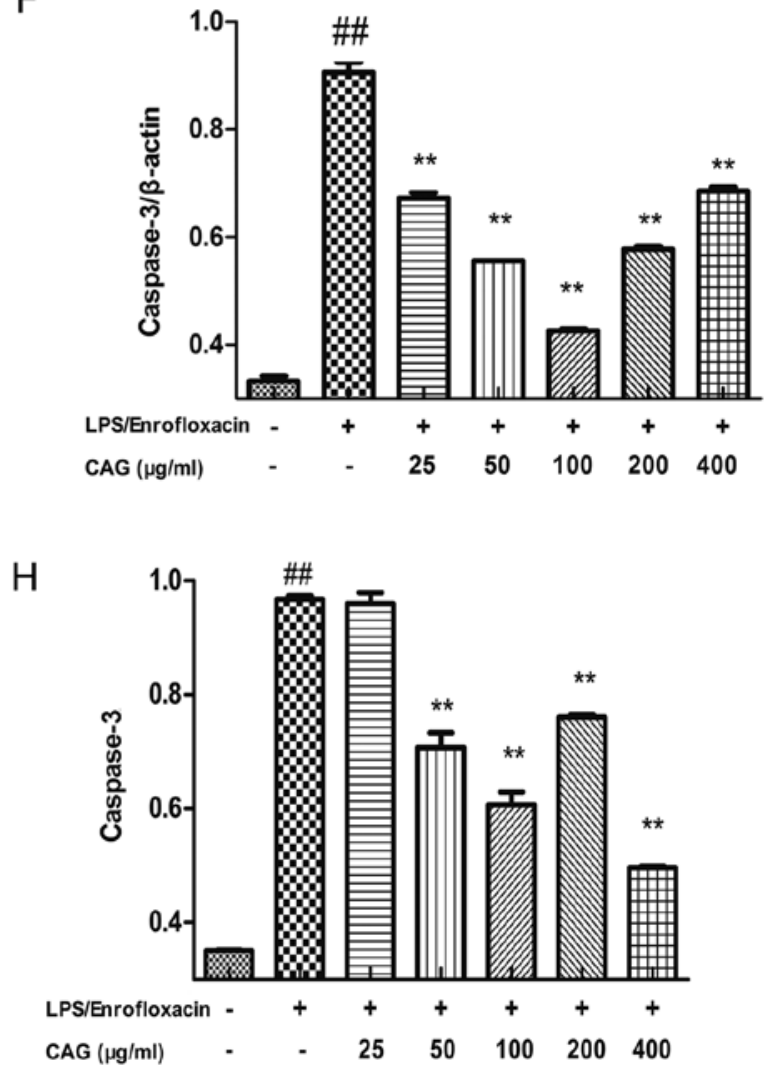

Figure 3. Effects of CAG treatment on the expression of (A) Caspase-3, (B) Bax and (C) Bcl-2. (D) Western blot analysis. Quantitative analysis of protein expression levels of (E) Bcl-2, (F) Caspase-3 and (G) Bax. $\beta$-actin was used as the reference gene. (H) Caspase-3 activity. Data are expressed as the mean \pm standard deviation (n=3). ${ }^{\# \#} \mathrm{P}<0.01$ vs. the control group; ${ }^{*} \mathrm{P}<0.05,{ }^{* *} \mathrm{P}<0.01$ vs. the model group treated with $30 / 80 \mu \mathrm{g} / \mathrm{ml}$ LPS/enrofloxacin. LPS, lipopolysaccharide; $\mathrm{CAG}$, composite ammonium glycyrrhizin; Bcl-2, apoptosis regulator Bcl-2; Bax, Bcl-2 associated X-protein. 

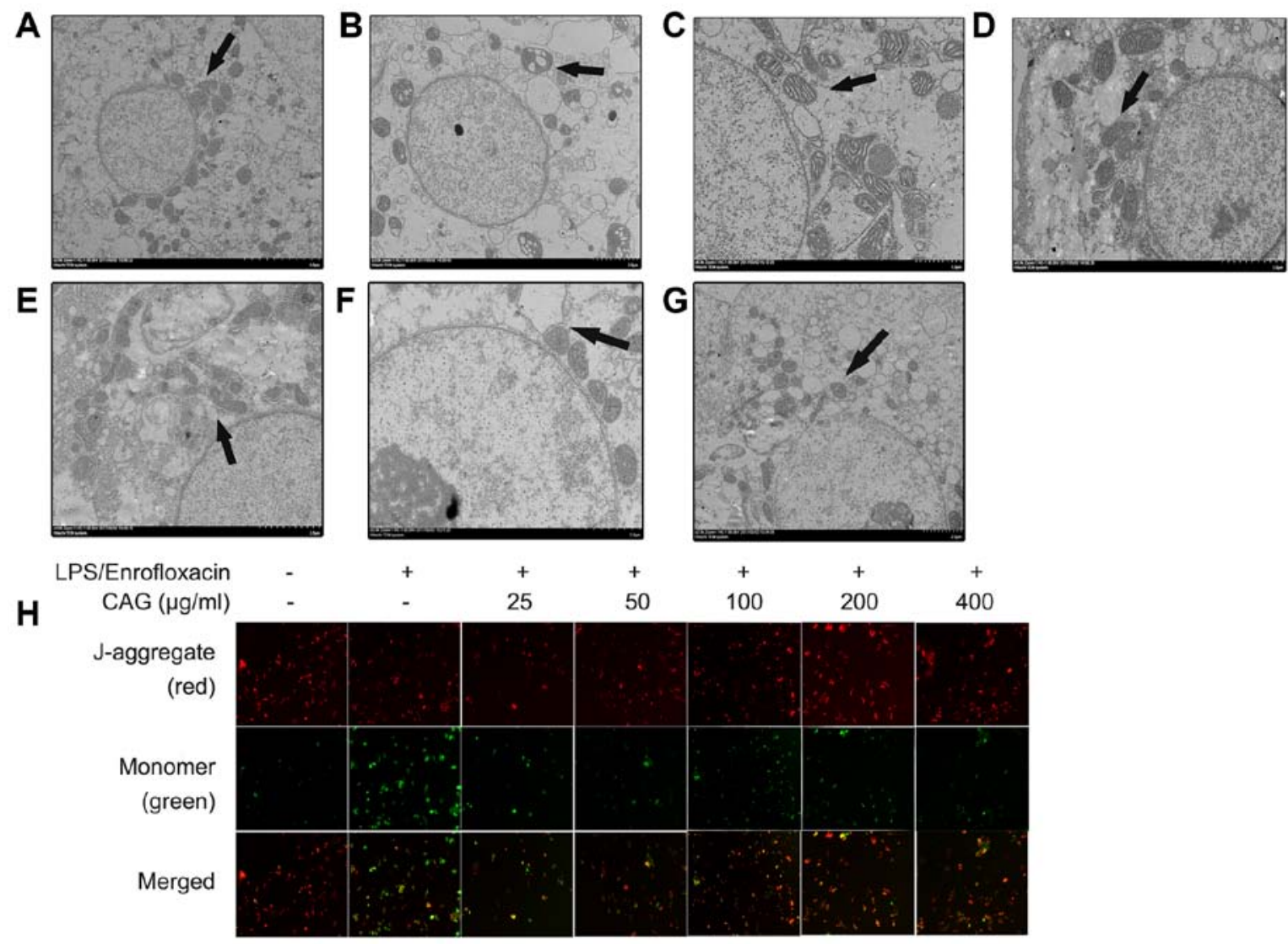

Figure 4. Ultrastructural features of chicken primary hepatocytes. (A) Control, (B) model group, (C) CAG group (25 $\mu \mathrm{g} / \mathrm{ml})$, (D) CAG group (50 $\mu \mathrm{g} / \mathrm{ml})$, (E) CAG group $(100 \mu \mathrm{g} / \mathrm{ml}),(\mathrm{F})$ CAG group $(200 \mu \mathrm{g} / \mathrm{ml})$ and (G) CAG group $(400 \mu \mathrm{g} / \mathrm{ml})$. The arrows indicate mitochondria. (H) $\Delta \Psi \mathrm{m}$ was measured using a fluorescent microscope (magnification, x100). In the model group the green fluorescence was increased compared with the red fluorescence compared with control group, CAG relieved these alterations. CAG, composite ammonium glycyrrhizin.

genase type IV ex-situ perfusion method. Primary hepatocytes displayed a high level of viability and purity. Unpublished results suggested the LPS and ENR doses required to induce hepatocyte injury in addition to their respective $\mathrm{IC}_{50}$ values, with LPS at $60 \mu \mathrm{g} / \mathrm{ml}$ and ENR at $180 \mu \mathrm{g} / \mathrm{ml}$. LPS/ENR treatment resulted in a dose-dependent increase in cell death; therefore a lower concentration of each component was used than required for modeling separately. In the present study it was observed that CAG relieved liver injury. Preliminary experiments demonstrated that LPS/ENR treatment significantly decreased cell viability and increased ALT and AST levels in the supernatant, and treatment with CAG improved these indicators. These results indicate that LPS/ENR induced in vitro liver injury and CAG may represent a promising therapeutic tool for the treatment of acute hepatic damage. Further investigation was also performed into the mechanisms behind LPS/ENR hepatotoxicity and the hepatoprotective effects of CAG, including hepatocyte apoptosis, hepatic oxidative stress and the expression of apoptosis-associated genes.

Protective effects on hepatocytes may be associated with antioxidant capacity via scavenging of reactive oxygen species (ROS) (27). The balance of intracellular ROS depends on the production of aerobic metabolism in normal cells in addition to non-enzymatic substances, such as MDA and enzyme antioxidants, including GSH, SOD, CAT and GPx (28). In the present study, high levels of MDA were collected from cell lysates in the model group, which indicated that LPS/ENR triggered the oxidation of liver cell membranes. The results demonstrated that CAG has the ability to restore lipid peroxidation of liver cells induced by LPS/ENR. It has been previously established that cellular antioxidant enzymes are the most important biomolecules for the prevention of oxidative stress (29). Antioxidants balance the cellular antioxidant system by inhibiting free radical production, thereby preventing toxin-induced hepatocyte injury (30). A previous study demonstrated that glycyrrhizin is effective at inhibiting lipid peroxidation and enhancing the capacity to eliminate free-radicals, revealing the antioxidative effects of CAG (20). The present study has demonstrated that LPS/ENR may initiate ROS overproduction and cause a reduction in the cellular anti-oxidant enzymes GSH, SOD, CAT and GPx in hepatocytes. The results also revealed that LPS/ENR treatment reduced antioxidant enzyme activity and increased lipid peroxidation. CAG pretreatment increased antioxidant enzyme levels.

Apoptosis is essential for maintaining multicellular organism development and the stability of the internal environment by eliminating excess or unwanted cells (31). Under pathological conditions (including chemically-induced lesions), the apoptotic balance may be disrupted, which leads to excessive and persistent apoptosis (32). Hepatocyte apoptosis has been revealed to serve an important role in viral and non-viral-induced acute liver injury $(33,34)$. The positive effect of CAG may be due to its ability to scavenge free radicals. Hepatocyte apoptosis is the most important molecular 
mechanism associated with liver failure $(35,36)$. Therefore, exploring the underlying mechanisms of apoptosis provides a basis for LPS/ENR-induced liver injury. Animal experiments have demonstrated that hepatocyte apoptosis significantly increased following LPS treatment (37). Conversely, glycyrrhizin was revealed to inhibit apoptosis in $\mathrm{CCl}_{4}$-induced liver injury in rats (38). In the present study, the results demonstrated an increase in the number of apoptotic hepatocytes in the LPS/ENR-treated group; these cells primarily comprised early apoptotic cells. In the CAG-treated group the number of early apoptotic cells decreased in a dose-dependent manner, indicating that CAG relieved liver injury caused by LPS/ENR.

The current study focused primarily on a variety of genes associated with cell death and the protease cascade system. Caspase-3 is an apoptosis effector, which has been reported to be a key factor in the apoptotic process (39). In addition, following examination of apoptotic chromatin condensation and DNA fragmentation, which are essential for the process of disassembling cells and the formation of apoptotic bodies, it was revealed that caspase- 3 was required (40). The results of the present study demonstrated that mRNA and caspase-3 activity increased following treatment with LPS/ENR, while CAG pretreatment significantly attenuated caspase-3 activity and its mRNA levels. In addition, mitochondria were observed to be swollen and vacuolated in the model group as revealed by TEM. The effect of LPS/ENR on MMP will be included in further studies.

The Bcl-2 family contains pro-apoptotic (Bax and Bid) and anti-apoptotic (Bcl-2 and Bcl-xl) proteins, which regulate the mitochondrial apoptotic signaling pathway (41). In addition, cell survival and death may be regulated by blocking death receptor formation and binding with the mitochondrial outer membrane (42). Bcl-2 and Bax have opposite effects on cell death; when Bcl-2 is higher than Bax it causes the inhibition of cell death, whereas Bax levels higher than Bcl-2 cause the acceleration of apoptosis (43). The results of the present study suggest that the Bcl-2 mRNA level was decreased in the LPS/ENR-treatment group results of the present study indicated that the protective effect of CAG against LPS/ENR-induced liver injury may be partly mediated by regulation of the apoptotic signaling pathway.

In conclusion, the present study demonstrated that ENR in combination with LPS exacerbate toxicity in chicken hepatocytes, whereas CAG relieves this toxicity. Therefore, CAG may have potential as a novel prophylactic agent for the treatment of hepatic liver disease. However, further studies are required to confirm the clinical viability of this treatment.

\section{Acknowledgements}

Not applicable.

\section{Funding}

The present study was supported by the National Natural Science Foundation (grant no. 31572569).

\section{Availability of data and materials}

The datasets used and/or analyzed during the present study are available from the corresponding author on reasonable request.

\section{Authors' contributions}

XG and $\mathrm{ZY}$ conceived and designed the experiments. WL and RA performed the experiments. WL, ZY and MH analyzed the data. WL drafted and revised the manuscript. All authors read and approved the final manuscript.

\section{Ethics approval and consent to participate}

The present study was approved by the Animal Ethics Committee of Nanjing Agricultural University (IACUC).

\section{Patient consent for publication}

Not applicable.

\section{Competing interests}

The authors declare that they have no competing interests.

\section{References}

1. Xia X, Su C, Fu J, Zhang P, Jiang X, Xu D, Hu L, Song E and Song Y: Role of $\alpha$-lipoic acid in LPS/d-GalN induced fulminant hepatic failure in mice: Studies on oxidative stress, inflammation and apoptosis. Int Immunopharmacol 22: 293-302, 2014.

2. Jeong YI, Jung ID, Lee CM, Chang JH, Chun SH, Noh KT, Jeong SK, Shin YK, Lee WS, Kang MS, et al: The novel role of platelet-activating factor in protecting mice against lipopolysaccharide-induced endotoxic shock. PLoS One 4: e6503, 2009.

3. Thirunavukkarasu C, Uemura T, Wang LF, Watkins SC and Gandhi CR: Normal rat hepatic stellate cells respond to endotoxin in LBP-independent manner to produce inhibitor(s) of DNA synthesis in hepatocytes. J Cell Physiol 204: 654-665, 2005.

4. Kaplowitz N: Drug-induced liver disorders: Implications for drug development and regulation. Drug Saf 24: 483-490, 2001.

5. Hirashima R, Itoh T, Tukey RH and Fujiwara R: Prediction of drug-induced liver injury using keratinocytes. J Appl Toxicol 37: 863-872, 2017.

6. Ghabril M, Chalasani N and Bjornsson E: Drug-induced liver injury: A clinical update. Curr Opin Gastroenterol 26: 222-226, 2010.

7. Leitner JM, Graninger W and Thalhammer F: Hepatotoxicity of antibacterials: Pathomechanisms and clinical. Infection 38: 3-11, 2010.

8. Yilmaz B, Ekiz F, Coban S, Yüksel I and Yüksel O: Cefixime-induced hepatotoxicity. Turk J Gastroenterol 22: 445, 2011.

9. Orman ES, Conjeevaram HS, Vuppalanchi R, Freston JW, Rochon J, Kleiner DE and Hayashi PH; DILIN Research Group: Clinical and histopathologic features of fluoroquinolone-induced liver injury. Clin Gastroenterol Hepatol 9: 517-523 e3, 2011.

10. Liu B, Cui Y, Brown PB, Ge X, Xie J and Xu P: Cytotoxic effects and apoptosis induction of enrofloxacin in hepatic cell line of grass carp (Ctenopharyngodon idellus). Fish Shellfish Immunol 47: 639-644, 2015.

11. Kalpana S, Aggarwal M, Srinivasa Rao G and Malik JK: Effects of aflatoxin B1 on tissue residues of enrofloxacin and its metabolite ciprofloxacin in broiler chickens. Environ Toxicol Pharmacol 33: 121-126, 2012.

12. Shinozuka Y, Uematsu K, Takagi M and Taura Y: Comparison of the amounts of endotoxin released from Escherichia coli after exposure to antibiotics and ozone: An in vitro evaluation. J Vet Med Sci 70: 419-422, 2008

13. Oh HM, Lee S, Park YN, Choi EJ, Choi JY, Kim JA, Kweon JH, Han WC, Choi SC, Han JK, et al: Ammonium glycyrrhizinate protects gastric epithelial cells from hydrogen peroxide-induced cell death. Exp Biol Med (Maywood) 234: 263-277, 2009.

14. Sato H, Goto W, Yamamura J, Kurokawa M, Kageyama S, Takahara T, Watanabe A and Shiraki K: Therapeutic basis of glycyrrhizin on chronic hepatitis B. Antiviral Res 30: 171-177, 1996. 
15. Yamamura Y, Kotaki H, Tanaka N, Aikawa T, Sawada Y and Iga T: The pharmacokinetics of glycyrrhizin and its restorative effect on hepatic function in patients with chronic hepatitis and in chronically carbon-tetrachloride-intoxicated rats. Biopharm Drug Dispos 18: 717-725, 1997.

16. Lin JC, Cherng JM, Hung MS, Baltina LA, Baltina L and Kondratenko R: Inhibitory effects of some derivatives of glycyrrhizic acid against Epstein-Barr virus infection: Structure-activity relationships. Antiviral Res 79: 6-11, 2008

17. Fiore C, Eisenhut M, Krausse R, Ragazzi E, Pellati D, Armanini D and Bielenberg J: Antiviral effects of glycyrrhiza species. Phytother Res 22: 141-148, 2008.

18. Seeff LB, Lindsay KL, Bacon BR, Kresina TF and Hoofnagle JH: Complementary and alternative medicine in chronic liver disease. Hepatology 34: 595-603, 2001.

19. Stickel F and Schuppan D: Herbal medicine in the treatment of liver diseases. Dig Liver Dis 39: 293-304, 2007.

20. Visavadiya NP and Narasimhacharya AV: Hypocholesterolaemic and antioxidant effects of glycyrrhiza glabra (Linn) in rats. Mol Nutr Food Res 50: 1080-1086, 2006.

21. Racková L, Jancinová V, Petríková M, Drábiková K, Nosál R, Stefek M, Kostálová D, Prónayová N and Kovácová M Mechanism of anti-inflammatory action of liquorice extract and glycyrrhizin. Nat Prod Res 21: 1234-1241, 2007.

22. Yim SB, Park SE and Lee CS: Protective effect of glycyrrhizin on 1-methyl-4-phenylpyridinium-induced mitochondrial damage and cell death in differentiated PC12 cells. J Pharmacol Exp Ther 321: 816-822, 2007.

23. LaBrecque DR and Howard RB: The preparation and characterization of intact isolated parenchymal cells from rat liver. Methods Cell Biol 14: 327-340, 1976.

24. Morikawa A, Sugiyama T, Kato Y, Koide N, Jiang GZ, Takahashi K, Tamada Y and Yokochi T: Apoptotic cell death in the response of D-galactosamine-sensitized mice to lipopolysaccharide as an experimental endotoxic shock model. Infect Immun 64: 734-738, 1996.

25. Livak KJ and Schmittgen TD: Analysis of relative gene expression data using real-time quantitative PCR and the 2(-Delta Delta C(T)) method. Methods 25: 402-408, 2001

26. Shiota M, Sugai N, Tamura M, Yamaguchi R, Fukushima N Miyano T and Miyazaki H: Correlation of mitogen-activated protein kinase activities with cell survival and apoptosis in porcine granulosa cells. Zoolog Sci 20: 193-201, 2003.

27. Szeto HH: Mitochondria-targeted peptide antioxidants: Novel neuroprotective agents. AAPS J 8: E521-E531, 2006.

28. Lowry OH, Rosebrough NJ, Farr AL and Randall RJ: Protein measurement with the Folin phenol reagent. J Biol Chem 193 265-275, 1951

29. Mohammadi M and Yazdanparast R: Methoxy VO-salen complex: In vitro antioxidant activity, cytotoxicity evaluation and protective effect on $\mathrm{CCl} 4$-induced oxidative stress in rats. Food Chem Toxicol 47: 716-721, 2009.
30. Song E, Fu J, Xia X, Su C and Song Y: Bazhen decoction protects against acetaminophen induced acute liver injury by inhibiting oxidative stress, inflammation and apoptosis in mice. PLoS One 9: e107405, 2014.

31. Srivastava M, Ma LQ, Singh N and Singh S: Antioxidant responses of hyper-accumulator and sensitive fern species to arsenic. J Exp Bot 56: 1335-1342, 2005.

32. ShamsabadiFT,Eidgahi MR, Mehrbod P,Daneshvar N, AllaudinZN, Yamchi A and Shahbazi M: Survivin, a promising gene for targeted cancer treatment. Asian Pac J Cancer Prev 17: 3711-3719, 2016.

33. Danial NN and Korsmeyer SJ: Cell death: Critical control points. Cell 116: 205-219, 2004.

34. Jaeschke H, Gujral JS and Bajt ML: Apoptosis and necrosis in liver disease. Liver Int 24: 85-89, 2004.

35. Kasahara I, Saitoh K and Nakamura K: Apoptosis in acute hepatic failure: Histopathological study of human liver tissue using the tunel method and immunohistochemistry. J Med Dent Sci 47: 167-175, 2000 .

36. Eichhorst ST: Modulation of apoptosis as a target for liver disease. Expert Opin Ther Targets 9: 83-99, 2005.

37. Togo S, Kubota T, Matsuo K, Shimizu T, Momiyama N, Takeda K, Tanaka K, Endo I, Sekido H and Shimada H: Mechanism of liver failure after hepatectomy. Nihon Geka Gakkai Zasshi 105: 658-663, 2004 (In Japanese).

38. Liu LM, Zhang JX, Luo J, Guo HX, Deng H, Chen JY and Sun SL: A role of cell apoptosis in lipopolysaccharide (LPS)-induced nonlethal liver injury in D-galactosamine (D-GalN)-sensitized rats. Dig Dis Sci 53: 1316-1324, 2008.

39. Wang XJ, Kong KM, Qi WL, Ye WL and Song PS Interleukin-1 beta induction of neuron apoptosis depends on p38 mitogen-activated protein kinase activity after spinal cord injury. Acta Pharmacol Sin 26: 934-942, 2005.

40. Guo XL, Liang B, Wang XW, Fan FG, Jin J, Lan R, Yang JH, Wang XC, Jin L and Cao Q: Glycyrrhizic acid attenuates $\mathrm{CCl}_{4}$-induced hepatocyte apoptosis in rats via a p53-mediated pathway. World J Gastroenterol 19: 3781-3791, 2013.

41. Chen XC, Zhu YG, Wang XZ, Zhu LA and Huang C: Protective effect of ginsenoside $\operatorname{Rg} 1$ on dopamine-induced apoptosis in PC12 cells. Acta Pharmacol Sin 22: 673-678, 2001.

42. Porter AG and Jänicke RU: Emerging roles of caspase-3 in apoptosis. Cell Death Differ 6: 99-104, 1999.

43. Wolter KG, Hsu YT, Smith CL, Nechushtan A, Xi XG and Youle RJ: Movement of Bax from the cytosol to mitochondria during apoptosis. J Cell Biol 139: 1281-1292, 1997.

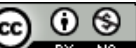

This work is licensed under a Creative Commons Attribution 4.0 International (CC BY-NC 4.0) License 